Transportation Research Forum

Book Review: The Men Who Loved Trains: The Story of Men Who Battled Greed to Save an Ailing Industry

Book Author(s): Rush Loving, Jr.

Review Author(s): Jack Ventura and Richard Klem

Source: Journal of the Transportation Research Forum, Vol. 49, No. 1 (Spring 2010), pp. 117-119

Published by: Transportation Research Forum

Stable URL: http://www.trforum.org/journal

The Transportation Research Forum, founded in 1958, is an independent, nonprofit organization of transportation professionals who conduct, use, and benefit from research. Its purpose is to provide an impartial meeting ground for carriers, shippers, government officials, consultants, university researchers, suppliers, and others seeking exchange of information and ideas related to both passenger and freight transportation. More information on the Transportation Research Forum can be found on the Web at www.trforum.org. 


\section{The Men Who Loved Trains}

\section{by Jack Ventura and Richard Klem}

Rush Loving's The Men Who Loved Trains is a journalistic work, the result of a long career (as associate editor of Fortune Magazine) covering the subject he writes about and of more than 200 interviews with principals over many years. His subject here is the reshaping of the eastern railroads in the last half of the $20^{\text {th }}$ century, but especially the executives that brought about the formation of Conrail and its subsequent split between CSX and Norfolk Southern.

We can discern four key story lines weaving their way through the book. The first is the one that gives the book its title. Clearly set forth at the beginning and recapped at the end is the principle that there are good guys-the men who loved trains-and the rest who didn't. The good guys are David R. Goode (Norfolk Southern (NS)), Alfred E. Perlman (New York Central (NYC)), W. Graham Claytor, Jr. (Southern Railway), Robert Claytor (NS), John Fishwick (Norfolk \& Western (N\&W)), Hays T. Watkins (CSX), L. Stanley Crane (Southern Railway), and James A. Hagen (Conrail (CR)). They understood the need to put money into their rail properties and to reap the rewards from doing so down the road. As a general proposition, Loving notes, men who love their industries make better managers than those who simply fill the roles of president or chairman; they work for less but accomplish more.

The rest who didn't love trains are numerous, but prominent by far among them is John Snow, who in the end is made to epitomize the genre. He is cast as a self-serving politician more than a railroader, credited with helping deregulation but not helping his railroad, CSX. He retired into his appointment as Treasury Secretary in 2002 with a golden parachute, though he, as Loving asserts, had not had a good record as executive leader and had been tight with capital investment to the point of raising operating costs and weakening CSX's ability to compete. But this is not to say that the good guys, the men who loved trains, come off as saints. Far from it, Loving unsparingly brings out their personality flaws. These flaws profoundly altered the course of the eastern railroads' restructuring, starting early on with the way Alfred Perlman put off other railroads' CEO's to where they were reluctant to deal with him.

This story line is both the book's greatest strength and weakness. It makes the book a fun read and provides many valuable facts and insights relating to the good guys, but the treatment of the bad guys is less successful to the point of weakening the book. In the interest of full disclosure, please note that one of the authors of this review worked for Snow as vice president for corporate strategy at CSX Corp. from 1988 to 1997 . Loving's two main complaints against Snow are that he under-invested in the railroad to the point of deferring maintenance and that he was flighty in the sense of drifting based on who spoke with him last. Deferred maintenance is a difficult thing to measure and Loving presents little evidence to support his claim. While it is not disputed that Conrail spent more on its physical plant than CSX did, the question should be was Conrail "gold plated" as some believed or was CSX deferring maintenance as others believed? While neither of us is qualified to make pronouncements on this, one of us attended periodic meetings of CSX's top management in which Snow repeatedly probed the question and was assured that there was no deferred maintenance. More importantly, hard evidence pertaining to safety, derailments, etc., was presented to support the assurances. In the 1990s CSX's safety performance did improve to the point it achieved rough parity with NS, which was no mean feat. Loving should have included quotes from reputable CSX operating executives such Jerry Davis.

As to Snow's lacking consistency, based on numerous observations, this probably arises from his propensity to talk to everyone and listen sympathetically, but to talk last to someone who shares 
his view on what the right course of action should be. Indeed, Loving identifies only two long term goals for Snow, to split Conrail with NS and to become a Cabinet Secretary. Did anyone else in this narrative achieve all of their identified long term goals?

The second key story line, and perhaps the one of most interest to railroad insiders, is that of the rearrangement of the eastern railroads from the 1950's, which in large part through the decades centered on who the weak Pennsylvania and New York Central railroads should go to. In sum, the dynamics of circumstances at the time and the key players' personalities led to Penn Central and later a unified Conrail, probably the worst result. The alignment that we eventually ended up with (essentially NS/Pennsylvania Railroad (PRR) and CSX/NYC) had come up early on and kept resurfacing over the years from time to time. As the N\&W kicked off the merger movement of the 1950's, Alfred Perlman presciently disliked a PRR-NYC union. In the three-way (Baltimore \& Ohio (B\&O), Chesapeake \& Ohio (C\&O), and NYC) talks that ensued the overhanging concern (Walt Tuohy's of C\&O) was that Perlman would dominate. The personality conflict between James Symes (PRR) and Perlman explains why the Penn Central merger got stalled in 1962, finally moving forward when Stuart Saunders (of PRR)-who was not anti-Jewish like Symes- was named CEO of the combined group. The Penn-Central merger was, from the start, riddled with problems arising from tension between the NYC and PRR factions. Lessons learned from that misadventure could have helped avert similar initial mishaps following some of the large mergers that came later. In the case of the Penn-Central, the operating plan the two roads had going into the merger fell apart. While Perlman met his end of the deal in pulling materials from small yards to build up the large automated facility at Selkirk, Saunders (who had come over from the N\&W to PRR) didn't do the same with the yard in Columbus, which would have rationalized the traffic flows between the two roads. The late 1990's ushered in the last stage in the Conrail saga, when it was split between CSX and Norfolk Southern. In the negotiations, Jim McClelland, then working for NS, was concerned that CSX would wind up with more than $35 \%$ of Conrail; a bidding war between CSX and NS ensued which pushed the stock price much higher. David LeVan, Conrail president, desperately fought to maintain Conrail's value, which resided in the "vaunted X" (that is, where the same network held the crossing of the route between Chicago and Pittsburgh and that between St. Louis and Cleveland). NS, on the other hand, worried that a CSX/CR merger would fall in the hands of Union Pacific, dwarfing the remaining BNSF/NS combination. The deal that the roads finally reached was brokered by STB Chairman Linda Morgan, assuming the role of what Loving dubs "a poor man's J. P. Morgan."

The third key story line is the recurring incidence of financial shenanigans, most eminently at Penn Central all the way to its collapse. Penn Central became the "grandaddy of Enron," as Loving puts it, with paper profits hiding huge losses. In 1970 Penn Central tried to float $\$ 100$ million in debentures overseas to avoid SEC disclosure rules. Failing in that, Penn Central management turned to the Federal Government for loan guarantees, all the while keeping in the dark the Board of Directors, who wound up seeing less of the road's true financial condition than the outsiders from which management sought loans or guarantees. With concern over effects on the economy of a Penn Central failure (not unlike the concerns in the Fall of 2008 over financial institutions then too big to fail), the Nixon Administration moved to arrange a Defense Department loan guarantee of \$200 million through a New York City Bank consortium, but under pressure from Democrats in Congress the Administration relented, the offer was withdrawn, and Penn Central proceeded to go into receivership.

Serving as the fourth and final story line is that of Jim McClellan as a Forest Gump popping up just about everywhere and at all times through the length and breadth of the book. McClellan managed to serve stints at Southern Railway, New York Central, Association of American Railroads, Federal Railroad Administration (FRA), United States Railway Association (USRA), Amtrak, and Norfolk Southern at every pivotal time in the contorted story of the restructuring of the northeast rail freight and passenger services in the second half of the $20^{\text {th }}$ century.

It is a fascinating story, but with so many characters seeming to replay similar situations involving the same railroads over the decades, it's a challenge to keep it all straight and to come 
away with a clear, unified story line. One would think that having Jim McClelland as a recurring figure through the book would help tie the story together, but it doesn't help that he kept changing jobs from one player to another in the story. It's doubtful that even a flow chart graphic would help here. However, the thesis that men who loved trains did better for their railroads than those who didn't seems to be borne out and would also seem to have support in economics. We would expect the former's greater care for the long-term physical and economic condition of their companies to have paid off better. All in all, we find the book worthy of attention from academics and researchers inasmuch as it brings a realistic perspective to the forces that shaped the rail industry in the East. We find it also an eye opener on the failings of corporate governance in the rail industry at a time when the industry was under full blown regulation by the Interstate Commerce Commission (ICC), with Penn Central engaging in financial machinations worthy of Enron later on.

To these reviewers, whose professional careers were intertwined with much of the restructuring activities related in this book, there was great interest in getting a look at what transpired on the inside among the central players. Other transportation professionals with similar experiences may have a similar reaction. For one of the reviewers, who actually calculated the 34 car per mile per year used as ICC's presumptive standard for judging the viability of lines proposed for abandonment, the revelation in the book that this was adopted as the rough and ready first cut for formulating the FRA's Orange Line report (1974, which led to USRA's Preliminary System Plan) was nothing short of astonishing. Similarly, this book may hold other fascinating surprises for others who were deeply involved but were not privy to the whole story.

The views expressed in this book review do not represent the views of the Surface Transportation Board or the United States but are solely the views of the authors.

Dr. Jack S. Ventura has served as economist at the Interstate Commerce Commission and its successor, the Surface Transportation Board, since 1965 in supervisory and non-supervisory positions. He led the ICC/STB economic teams reviewing the rail mergers of the 1990's, including the Conrail split case. He has a B.A. in economics from Columbia College (1964), an M.A. in applied economics (transportation and public utilities) from the University of Pennsylvania (1965), and a Ph.D. in economics from Georgetown University (1970). He serves as president of the TRF Foundation, book review editor of the Journal of the TRF, and treasurer of the TRF Washington Chapter.

Dr. Richard Klem has a Ph.D. in economics from Northwestern University and has been in the transportation field since the 1970s, when he taught transportation at the university level and then joined the Office of the Secretary of the U.S. DOT as an analyst. He has had several high level jobs in the U.S. Government and is currently a policy advisor in the Office of Economics, Environmental Analysis, and Administration of the STB. From 1988 to 1997 he was assistant vice president and then vice president for corporate strategy of CSX Corp. 